\title{
Importance of knowledge of the management of traumatic dental injuries in emergency departments
}

\author{
Acar Aren, M.D.,, Arzu Pınar Erdem, M.D., ${ }^{2}$ Gamze Aren, M.D., ${ }^{2}$ Zeynep Deniz Şahin, M.D., ${ }^{1}$ \\ Ceren Güney Tolgay, M.D., ${ }^{2}$ Merve Çayırcı, M.D., ${ }^{2}$ Elif Sepet, M.D., ${ }^{2}$ Recep Güloğlu, M.D., ${ }^{3}$ \\ Hakan Yanar, M.D., ${ }^{3}$ Kaya Sarıbeyoğlu, M.D. ${ }^{4}$
}

\begin{abstract}
${ }^{1}$ Department of General Surgery, İstanbul Training and Research Hospital, İstanbul-Turkey
2Deparment of Pediatric Dentistry, İstanbul University Faculty of Dentistry, İstanbul-Turkey

${ }^{3}$ Deparment of General Surgery, İstanbul University İstanbul Faculty of Medicine, İstanbul-Turkey

${ }^{4}$ Deparment of of General Surgery, İstanbul University Cerrahpaşa Faculty of Medicine, İstanbul-Turkey
\end{abstract}

\begin{abstract}
BACKGROUND: Hospital emergency departments (EDs) are confronted with managing dental emergencies of both traumatic and non-traumatic origin. However, the literature suggests inadequate knowledge of the management of traumatic dental injuries (TDIs) among medical professionals. The aim of this study was to investigate the knowledge and attitudes regarding management of TDls among Istanbul ED physicians.
\end{abstract}

METHODS: Surveys were distributed to emergency departments (ED) directors and their physicians. The survey contained questions about their characteristics and tested their knowledge of managing dental trauma.

RESULTS: A total of 126 surveys (I 3 ED directors and II 3 physicians) were returned and included in the analysis. ED physician's knowledge of the appropriate management of crown fractures and avulsion was generally good $(p=0.22 I)$, but poor for luxation injuries $(p=0.000 \mathrm{I})$. Physicians were more likely to have a better knowledge about permanent teeth than about $p$ rimary teeth $(p=0.027)$.

CONCLUSION: Education, monitoring, improved availability of resources, and disciplinary measures in cases of poor compliance are necessary to improve TDI management in hospitals, especially among physicians.

Keywords: Dental trauma; orofacial injury; traumatic dental injuries.

\section{INTRODUCTION}

Several epidemiological studies continue to show significant levels of dental trauma in many countries. ${ }^{[1-3]}$ In industrialized countries, about one in five children experience a traumatic dental injury (TDI) to permanent teeth before leaving school. Prevalence of injured teeth reported in the literature varies from $10 \%$ to $51 \% .{ }^{[4,5]}$ The nature and complexity of dental trauma in children vary widely. ${ }^{[6]}$ Prompt and appropriate management is necessary to significantly improve prognosis of many dentoalveolar injuries, especially in a young patient. ${ }^{[7-9]}$
The emergency medical service doctors are frequently the first to provide the primary treatment. ${ }^{[10]}$ It has been well documented that the prognosis of traumatized teeth depends largely on both timely and appropriate emergency management. ${ }^{[6]}$ Tooth fracture affecting the pulp, luxation injuries, and, especially, avulsions require prompt evaluation and treatment to obtain the best possible outcomes. Delays in treatment may result in poor prognoses of a child's tooth/teeth that have sustained these time-sensitive dental injuries. ${ }^{\left[{ }^{[I]}\right]}$ To ensure appropriate treatment of children with dental trauma, it is essential that emergency medical professionals are adequately trained in the basic principles of dental trauma management. ${ }^{[10]}$

Cite this article as: Aren A, Erdem AP, Aren G, Şahin ZD, Güney Tolgay C, Çayırcı M, et al. Importance of knowledge of the management of traumatic dental injuries in emergency departments. Ulus Travma Acil Cerrahi Derg 2018;24:136-144

Address for correspondence: Acar Aren, M.D.

İstanbul Eğitim ve Araştırma Hastanesi, Genel Cerrahi Kliniği, İstanbul, Turkey

Tel: +90 212 - 5884400 / 1576 E-mail: acararen@gmail.com

Ulus Travma Acil Cerrahi Derg 2018;24(2):136-144 DOI: 10.5505/tites.2017.57384 Submitted: 04.12.2016 Accepted: 24.05.2017 Online: 14.02.2018

Copyright 2018 Turkish Association of Trauma and Emergency Surgery 
In our previous article about predominant causes and types of orofacial injury in children seen in the emergency department (ED), ${ }^{[12]}$ a total of 1296 children among 12055 patients with orofacial trauma were evaluated. Although there is a high probability of encountering orofacial trauma, our search of the literature revealed only one study from Turkey that evaluated the knowledge of medical professionals in the management of tooth avulsion injuries. Therefore, this study aimed to evaluate the first-aid knowledge of the emergency physicians on the management of common pediatric dental traumas such complicated/uncomplicated crown fractures, luxation, and avulsion.

\section{MATERIALS AND METHODS}

The present study was a cross-sectional observational study. The project was approved by the Ethics Committee of Istanbul University, Faculty of Dentistry (20I5/24). The nature and purpose of the study was explained to all participants, its voluntary nature emphasized. Informed consent to participate was subsequently obtained from each study participant. Strict confidentiality was assured as no names or phone numbers were required.

The survey was developed by gathering the questions used in the articles of Needleman, Subhashraj, and Addo. ${ }^{[1,13,14]}$ In addition, physicians' experience in first-aid management of dental trauma was examined with new questions framed by the authors. The original questionnaire was developed and piloted to 10 volunteers and revised before being completed by the first group of participants. The survey was distributed to the emergency rooms departments of Istanbul University Faculty of Istanbul Medicine and Faculty of Cerrahpaşa Medicine and Health Science University Istanbul Training and Research Hospital.

The questionnaire was divided into three parts. The first part comprised questions on personal information. It included information about (age, gender, year of medical graduation, profession, academic title, level of experience in emergency medicine, if first-aid training included training on dental trauma and if the medical training involved any dental educational programs, whether the participants find their knowledge of dental trauma management sufficient or not, previous experience, and interest in learning dental trauma management). Parts II and III comprised questions regarding uncomplicated crown fracture, complicated crown fracture, luxation, and avulsion of both primary and permanent teeth as well as the emergent nature of each of these injuries. The multiple-choice or yes/no questions were used. The survey was given to the participants under the supervision of the authors.

The following fields of knowledge were assessed: importance of the emergent treatment of complicated crown fractures for pulpal healing, management of luxation, importance of immediate management of an avulsed permanent tooth for the long-term success, importance of not replanting primary teeth, optimal storage media, critical extra-alveolar time of an avulsed tooth, proper handling of an avulsed tooth, proper cleaning technique for an avulsed tooth before replantation, first place to contact in seeking professional help, and dental trauma experience.

The guidelines for managing TDI as published at that time by the International Association of Dental Traumatology were used to determine the correct choice for each trauma question in the survey as defined by Needleman, Diaz, and coworkers. ${ }^{[1,15]}$

\section{Statistical Analyses}

Data were analyzed using NCSS (Number Cruncher Statistical System) 2007 Statistical Software (Utah, USA). A descriptive analysis including average, standard deviations, medians, minimum, and maximum was performed. We performed oneway analysis of variance for different groups and Tukey's multiple comparison test for subgroups; Independent t-test was also performed. The results were considered to be significant for $\mathrm{p}<0.05$.

\section{RESULTS}

In total, 126 physicians participated in the study; $72.22 \%$ of the participants were male and $27.78 \%$ were female. The mean age of the participants was $36.67 \pm 8.87$ years.

The first part of the questionnaire included the personal data of the physicians. Personal data has been summarized in Table I; $73.81 \%$ of the respondents were general surgeons and $89.68 \%$ were medical specialists.

In this study, the mean of professional experience duration was 10.73 \pm 8.82 . The professional experience duration was calculated taking into account the time spent in this area after receiving the title of medical specialist. Experience level in emergency medicine was calculated as taking in consideration of the emergency service working time and it was 9.10 07.98 years.

$72.22 \%$ of the participants did not receive any training on oral and dental health and $\mathbf{9 7 . 6 2 \% ~ d i d ~ n o t ~ a t t e n d ~ a n y ~ d e n - ~}$ tal trauma management training. Three participants reported that they received education on dental trauma at a medical faculty. Of all the physicians, $84.92 \%$ stated that their knowledge of dental trauma management was insufficient and $80.80 \%$ were willing to attend training on this subject.

Knowledge of the appropriate emergent treatment for dental fractures, both uncomplicated and complicated, was satisfactory as indicated by physicians' correct response rates between $65.08 \%-92.86 \%$. The questions regarding emergent treatment need of lateral luxation cases, where primary or 
Table I. (a) Personal data of the physicians (b) Knowledge of TDI management (c) Interest in TDI management (d) Experience in emergency medicine

(a) Personal data of the physicians

n

Profession

General Surgery

Internal Medicine

Pediatrics

Emergency Medicine

Academic Title

Medical specialist

Assistant professor

Associate professor

Professor

Did you attend any oral health training during your educational/professional career?

No

Yes

Did you attend any dental trauma management training during your educational/professional career?

No

Yes

If the answer is yes, when did you attend?

No answer given

$5^{\text {th }}$ grade of medical faculty

(b) Knowledge of traumatic dental injuries management

Do you think you have sufficient knowledge of dental trauma?

Yes, my knowledge is sufficient

My knowledge is almost sufficient

No, not sufficient

I have no idea

\section{(c) Interest in traumatic dental injuries management}

If a dental trauma management training was given, would you attend?

Yes, I am interested

No, I am not interested

I have no idea

4

\begin{tabular}{lllcrr}
\hline (d) Experience in emergency medicine & $\mathbf{n}$ & Mean & Standar deviation & Minimum & Maximum \\
\hline Years of experience & 126 & 10.73 & 8.82 & 1 & 35 \\
Years of experience in emergency medicine & 124 & 9.10 & 7.98 & 0 & 35 \\
\hline
\end{tabular}

permanent teeth are displaced by $\mathrm{I}-2 \mathrm{~mm}$ without traumatic occlusion, were correctly responded to in the range of $65.08 \%-76.19 \%$. However, the correct response ratio for questions regarding the emergent nature of avulsion injuries was low (26.19\%-53.97\%). Table 2 presents the percentage of physicians' correct responses to each of the questions regarding emergent nature of treatment of dental fractures and luxation of primary/permanent teeth.
Correct response ratios between crown fracture, luxation, and avulsion question groups were significantly different $(p=0.000 \mathrm{l})$ (Table 3$)$. Luxation question group had less correct responses than crown fracture and avulsion groups $(p=0.000 \mathrm{I})$. No significant differences were observed between crown fracture and avulsion question groups $(p=0.22 \mathrm{l})$. Correct responses to permanent teeth questions were higher than those to primary teeth questions $(p=0.027)$. 
Table 2. Correct responses regarding the emergent management of TDI as a function of the type of injury (crown fracture, luxation, and avulsion) (a) and tooth type (primary vs permanent) (b)

\begin{tabular}{|c|c|c|c|c|c|}
\hline (a) & Mean $\pm S D$ correct response to survey questions & Median & Minimum & Maximum & p \\
\hline Crown fracture & $1.04 \pm 0.76$ & 1 & 0 & 3 & 0.0001 \\
\hline Luxation & $0.59 \pm 0.75$ & 0 & 0 & 2 & \\
\hline Avulsion & $1.2 \pm 0.77$ & 1 & 0 & 2 & \\
\hline (b) & Mean $\pm S D$ correct of survey questions & Median & Minimum & Maximum & $\mathbf{p}$ \\
\hline Primary teeth & $\mid .31 \pm 0.70$ & 1 & 0 & 3 & 0.027 \\
\hline Permanent teeth & $1.52 \pm 0.78$ & 2 & 0 & 3 & \\
\hline
\end{tabular}

Table 3. Comparison of correct responses among different question groups

\begin{tabular}{lc}
\hline & $\mathbf{p}$ \\
\hline Crown fracture / Luxation & 0.0001 \\
Crown fracture / Avulsion & 0.221 \\
Luxation / Avulsion & 0.0001 \\
\hline
\end{tabular}

Last part of the questionnaire included detailed questions regarding the management of avulsion (if treatment is needed in cases of permanent tooth avulsion, proper management of the avulsed tooth, proper cleaning technique of an avulsed tooth before replantation, proper handling of an avulsed tooth, optimal storage media, and prescription of antibiotics). Responses were grouped as "correct," "incorrect," and "no comment"; Table 4 presents the percentages of the responses.

While the incorrect response ratio for the question "Should avulsed permanent tooth be replaced?" was 30.95\%, 56.35\% of the participants declared that they have no idea; $10.32 \%$ of the physicians were aware of the appropriate treatment of an avulsed tooth. The correct response ratio for questions "If the tooth looks dirty, what would you do?" and "From which part would you hold the tooth?" was $50.79 \%$ and $48.41 \%$, respectively. The correct response ratio for the question re- garding appropriate storage media was very high (94.54\%). Table 5 presents the distribution of responses to questions regarding appropriate storage media. The majority of respondents $(80.96 \%)$ stated they would prescribe antibiotic and anti-inflammatory medicaments following avulsion, which was considered the correct response regarding treatment.

Critical extra-alveolar time of the avulsed tooth and first place to contact in seeking professional help were also questioned. Responses to these questions were distributed as the best response getting the highest score and the worse getting the lowest score [Table $6(\mathrm{a}, \mathrm{b})]$. When we evaluated the duration between avulsion and seeking professional help, the response of $26.19 \%$ of the participants was immediately, that of $5.87 \%$ was in a couple of hours, and that of $19.05 \%$ was within $24 \mathrm{~h}$; $7.14 \%$ participants responded that there was no need for urgent professional help and $19.05 \%$ had no idea about situation. For professional help, only $7.94 \%$ participants preferred a dentist and $1.59 \%$ preferred a pediatric dentist, which is very low.

Physicians' dental trauma experiences were also examined in the last part of the questionnaire.

Participants' previous experiences of dental trauma, with type and reason, were evaluated. Their knowledge about clinics in Istanbul that can manage emergency dental trauma cases and working hours of such clinics was also asked.

Table 4. Distribution of the responses to questions regarding avulsion injury

\begin{tabular}{|c|c|c|c|c|c|c|}
\hline & \multicolumn{2}{|c|}{ Correct responses } & \multicolumn{2}{|c|}{ Incorrect responses } & \multicolumn{2}{|c|}{ No comment } \\
\hline & $\mathbf{n}$ & $\%$ & $\mathbf{n}$ & $\%$ & $\mathbf{n}$ & $\%$ \\
\hline Should avulsed permanent tooth be replaced? & 16 & 12.7 & 39 & 30.95 & 71 & 56.35 \\
\hline What is the appropriate treatment of avulsed tooth? & 13 & 10.32 & 89 & 70.63 & 24 & 19.05 \\
\hline If the tooth looks dirty, what would you do? & 64 & 50.79 & 26 & 20.64 & 36 & 28.57 \\
\hline From which part would you hold the tooth? & 61 & 48.41 & 3 & 2.38 & 62 & 49.21 \\
\hline Which storage media are appropriate for the avulsed tooth? & 119 & 94.54 & 80 & 63.48 & 20 & 15.87 \\
\hline Would you prescribe antibiotics after avulsion? & 102 & 80.96 & 24 & 19.05 & 0 & 0 \\
\hline
\end{tabular}


Table 5. Distribution of responses to questions regarding appropriate storage media

\begin{tabular}{lcc}
\hline & n & $\%$ \\
\hline Correct responses & & \\
$\quad$ Saline solution & 79 & 62.70 \\
Salt water & 19 & 15.08 \\
Patient's mouth & II & 8.73 \\
Contact lens solution & 5 & 3.97 \\
Milk & 5 & 3.97 \\
Incorrect responses & & \\
Cold water & 30 & 23.81 \\
Paper towel/gauze & 11 & 8.73 \\
Disinfectant solution & 10 & 7.94 \\
Plastic bag & 9 & 7.14 \\
There's no need to keep the tooth & 6 & 4.76 \\
Ice & 5 & 3.94 \\
Tap water & 4 & 3.17 \\
Coke & 4 & 3.17 \\
Hot water & 1 & 0.79 \\
No idea & 20 & 15.87 \\
\hline & & \\
& &
\end{tabular}

Their opinions on interfering with dental trauma cases were estimated [Table 7 (a, b)]; $55.56 \%$ of the physicians had experienced a dental trauma and $50.79 \%$ had witnessed tooth fracture. Reasons for the trauma were traffic accident (32.54\%), fall (35.7I\%), sports accident (10.32\%), and stroke (28.57\%). Of all, $88.89 \%$ of the physicians were not aware of the emergency clinics managing dental trauma in Istanbul and their working hours. While witnessing a dental trauma, $44.44 \%$ and $27.78 \%$ of the physicians do not interfere with the patient because of lack of knowledge and because of legal obligations, respectively.

No significant differences were found between the demographic features of physicians and correct response ratios (Table 8).

\section{DISCUSSION}

This study aimed to evaluate the first-aid knowledge of the medical hospital ED physicians about the management of the common pediatric dental traumas. In our previous article, we reported that a high number of children visited EDs with orofacial injury complaints. ${ }^{[12]}$ Although high probability of orofacial trauma exists, our search of the literature revealed only one study from Turkey that evaluated the knowledge of medical professionals in the management of tooth avulsion injuries. ${ }^{[16]}$ Because an emergency dental practitioner is rarely present in public or university hospitals in Turkey, it is inevitable that physicians will sometimes be required to provide emergency dental treatment before professional dental contact.
Table 6. Extra-alveolar time of the avulsed tooth (a) the preference of professional help (b)

\begin{tabular}{llr}
\hline (a) Extra-alveolar time of the avulsed tooth & \multicolumn{2}{c}{ All groups } \\
\cline { 2 - 4 } & n & $\%$ \\
\hline In case of avulsion, when should the patient & & \\
seek professional help? & 33 & 26.19 \\
$\quad$ Immediately (score: 5) & 24 & 19.05 \\
Within first 24 h (score: 2) & 24 & 19.05 \\
I have no idea & 20 & 15.87 \\
Within 30-60 minutes (score: 4) & 16 & 12.70 \\
Within a few hours (score: 3) & & \\
There is no need for professional & 9 & 7.14 \\
help (score: I) & 9 &
\end{tabular}

(b) Preference for professional help All groups

n $\%$

Which one would you communicate with

for the treatment?

\begin{tabular}{lcc} 
Medical doctor (score: 3 ) & 103 & 81.75 \\
Dentist (score: 4) & 10 & 7.94 \\
There is no need for treatment (score: I) & 5 & 3.97 \\
I would treat by myself (score: 6 ) & 4 & 3.17 \\
Pediatric dentist (score: 5) & 2 & 1.59 \\
Plastic surgeon (score: 2 ) & I & 0.79 \\
I have no idea & I & 0.79 \\
\hline
\end{tabular}

Unlike most of the previously cited studies, ${ }^{[10,14-20]}$ which primarily queried physicians about avulsions, our study examines the management of the common pediatric dental traumas such as complicated/uncomplicated crown fractures, luxation, and avulsion.

Díaz et al. ${ }^{[15]}$ interviewed 82 medical staff in hospital emergency rooms in Chile; $90 \%$ of them had not received formal training, and it was concluded that the overall TDI knowledge was relatively poor. In 20II, Trivedy et al. ${ }^{[20]}$ found that the majority (88\%) of the physicians in the United Kingdom did not receive any formal training in TDI, and they were not confident in managing dentofacial emergencies. Ulusoy et al. ${ }^{[16]}$ reported that $41 \%$ of the respondents assessed their knowledge as insufficient, and the majority (78\%) stated that they would like further education. All of these studies reveal that physicians have an inadequate understanding of providing appropriate first-aid when confronted with TDI. In this study, the professional experience duration and experience level of the study group in emergency medicine were approximately 10 years. During this period, the majority of the physicians did not get any education about oral health or dental trauma management. 
Table 7. (a) Previous experience of dental trauma, (b) behavior of the physician facing dental trauma

\begin{tabular}{|c|c|c|c|}
\hline (a) Previous experience of dental trauma & & $\mathbf{n}$ & $\%$ \\
\hline \multirow[t]{2}{*}{ Have you ever witnessed a dental trauma incident? } & No & 56 & 44.44 \\
\hline & Yes & 70 & 55.56 \\
\hline Type of trauma & No & 103 & 81.75 \\
\hline & Yes & 23 & 18.25 \\
\hline Tooth fracture & No & 62 & 49.21 \\
\hline & Yes & 64 & 50.79 \\
\hline Luxation & No & 112 & 88.89 \\
\hline & Yes & 14 & II.II \\
\hline \multicolumn{4}{|l|}{ Reason of trauma } \\
\hline \multirow[t]{2}{*}{ Traffic accident } & No & 85 & 67.46 \\
\hline & Yes & 41 & 32.54 \\
\hline \multirow[t]{2}{*}{ Fall } & No & 81 & 64.29 \\
\hline & Yes & 45 & 35.71 \\
\hline \multirow[t]{2}{*}{ Sports accident } & No & 113 & 89.68 \\
\hline & Yes & 13 & 10.32 \\
\hline \multirow[t]{2}{*}{ Stroke } & No & 90 & 71.43 \\
\hline & Yes & 36 & 28.57 \\
\hline \multirow[t]{2}{*}{ Others } & No & 124 & 98.41 \\
\hline & Yes & 2 & 1.59 \\
\hline \multicolumn{2}{|l|}{ (b) Behavior of the physician witnessing dental trauma } & $\mathbf{n}$ & $\%$ \\
\hline \multicolumn{4}{|c|}{ If you are present at the scene of dental trauma accident, and the tooth is avulsed } \\
\hline \multicolumn{2}{|l|}{ I would not do anything because I do not know what to do } & 56 & 44.44 \\
\hline \multicolumn{2}{|l|}{ I would not do anything because of legal issues } & 35 & 27.78 \\
\hline \multicolumn{2}{|l|}{ I would confidently replant the tooth } & 2 & 1.59 \\
\hline \multicolumn{2}{|l|}{ I would try to replant the tooth, without surety } & I & 0.79 \\
\hline \multicolumn{2}{|l|}{ I have no idea } & 32 & 25.40 \\
\hline Are you familiar with dental clinics and their workings hours in Istanbul & No & 112 & 88.89 \\
\hline that can manage emergency dental trauma cases? & Yes & 14 & II.II \\
\hline
\end{tabular}

Only three participants had attended a lecture on TDI in medical faculty. Furthermore, $84.92 \%$ of the physicians found their knowledge of TDI to be insufficient and were willing to get educated on this subject. The results of this study are similar to those of other studies, revealing the inefficient knowledge of dental trauma management among ED physicians.

The physicians' knowledge of the appropriate emergency treatment for dental fractures, both uncomplicated and complicated, was satisfactory as indicated by their correct response rates between $65.08 \%$ and $92.86 \%$. The questions regarding lateral luxation injuries, which cause $\mathrm{I}-2 \mathrm{~mm}$ displacement of the permanent/primary teeth without traumatic occlusion, were mostly correctly responded to (between $65.08 \%$ and $76.19 \%$ ). However, questions regarding avulsion injuries had a low correct response ratio (26.19\%-53.97\%). Questions regarding luxation had a lower correct response ratio than those regarding crown fractures and avulsion $(p=0.000 \mathrm{I})$; no significant difference was found between correct responses to questions regarding crown fractures and avulsion $(p=0.221)$. Questions regarding permanent teeth had a significantly higher correct response ratio than those regarding primary teeth $(p=0.027)$.

Needleman ${ }^{[I]}$ and coworkers stated contrary results when comparing emergency physicians in Turkey. They reported poor knowledge about dental fractures, both uncomplicated and complicated, and good responses to luxation and avulsions, especially avulsions. Similar to Needleman et al., physicians' knowledge of TDI to permanent teeth was found to be better than that to primary teeth. 
Table 8. Analyses of association between the characteristics of various emergency department physicians and their knowledge of emergency management of dental trauma as determined by the mean number of correct responses to eight survey questions regarding complicated/uncomplicated crown fractures, luxation, and avulsion

\begin{tabular}{|c|c|c|c|c|c|c|c|}
\hline Physician/Institution characteristics & $\begin{array}{c}\text { No. of } \\
\text { physicians }\end{array}$ & $\begin{array}{c}\% \text { of } \\
\text { physicians }\end{array}$ & $\begin{array}{l}\text { Mean } \pm S D \text { correct responses } \\
\text { to eight survey questions }\end{array}$ & Median & Min. & Max. & $\mathbf{p}$ \\
\hline \multicolumn{8}{|l|}{ Age } \\
\hline $20-39$ years of age & 91 & 72.80 & $9.84 \pm 2.41$ & 10 & 4 & 18 & 0.272 \\
\hline $40-49$ years of age & 20 & 16.00 & $8.95 \pm 1.79$ & 8 & 6 & 13 & \\
\hline $50-69$ years of age & 14 & 11.20 & $9.36 \pm 2.34$ & 9.8 & 5 & 14 & \\
\hline \multicolumn{8}{|l|}{ Sex } \\
\hline Men & 91 & 72.80 & $9.55 \pm 2.39$ & 9 & 5 & 18 & 0.478 \\
\hline Women & 34 & 27.20 & $9.88 \pm 2.17$ & 10 & 4 & 13 & \\
\hline \multicolumn{8}{|l|}{ Specialty } \\
\hline General surgery & 96 & 76.2 & $9.58 \pm 2.41$ & 9 & 5 & 18 & 0.664 \\
\hline Pediatrics & 10 & 8.00 & $10.5 \pm 1.58$ & 10.5 & 8 & 13 & \\
\hline Internal medicine & II & 8.7 & $9.67 \pm 1.94$ & 10 & 7 & 13 & \\
\hline Emergency Medicine & 9 & 7.1 & $9,33 \pm 2.45$ & 10 & 4 & 13 & \\
\hline \multicolumn{8}{|l|}{ Professional experience } \\
\hline $0-5$ years & 46 & 36.80 & $9.8 \pm 2.17$ & 10 & 4 & 14 & 0.731 \\
\hline $6-10$ years & 31 & 24.80 & $9.87 \pm 2.43$ & 10 & 6 & 16 & \\
\hline $11-15$ years & 18 & 14.40 & $9.61 \pm 2.87$ & 8 & 7 & 18 & \\
\hline $16-20$ years & 7 & 5.60 & $9.57 \pm 2.76$ & 9 & 6 & 13 & \\
\hline$>20$ years & 23 & 18.40 & $9.04 \pm 1.94$ & 9 & 5 & 14 & \\
\hline \multicolumn{8}{|l|}{ Academic position } \\
\hline Medical specialist & 112 & 89.60 & $9.7 I \pm 2.31$ & 10 & 4 & 18 & 0.226 \\
\hline Assistant professor & 2 & 1.60 & $7 \pm 2.83$ & 7 & 5 & 9 & \\
\hline Associate professor & 8 & 6.40 & $10 \pm 2.51$ & 9.5 & 7 & 14 & \\
\hline Professor & 3 & 2.40 & $8 \pm 1$ & 8 & 7 & 9 & \\
\hline
\end{tabular}

In the present study, it was found that the age, gender, medical specialization, academic title, and experience level in emergency medicine of the respondents had no significant effect on emergency physicians' correct responses regarding emergency treatment for complicated/uncomplicated crown fractures, luxation, and avulsion $(p>0.05)$. Needleman ${ }^{\left[{ }^{[I]}\right.}$ and coworkers also reported the same results about the effect of ED physicians' characteristics on the knowledge of TDI. In previously cited studies, the correct answers about appropriate knowledge of avulsion management stated in a very wide range $3 \%$ to $50 \%$. $^{[10,18]}$

A favorable prognosis for avulsed and replanted teeth significantly depends upon the combination of minimal time spent outside the socket, appropriate storage and transportation media, and minimal aggression to the root surface and periodontal ligament. ${ }^{[2]}$ In this study, regarding the question if an avulsed permanent tooth should be replanted when the patient doesn't have any systemic disorder, only $12.70 \%$ of the participants agreed to put the tooth back in its socket; $3.92 \%$ of the physicians stated that an avulsed permanent incisor should be replanted in any event, while $24.6 \%$ of them would not replant an avulsed tooth under any circumstances, and $56.35 \%$ of respondents did not have any idea. In a study by Holan and Shmueli ${ }^{[10]}$ at Israel, $4 \%$ of the physicians stated that an avulsed permanent incisor should be replanted in any event, while Mclntyre et al. ${ }^{[22]}$ reported that approximately $72 \%$ of the respondents would not immediately replant an avulsed tooth. The data of Hamilton et al. ${ }^{[2]}$ showed that $36.4 \%$ of respondents did not know a tooth could be replanted. In the study of Abu-Dawoud et al.," ${ }^{[17]}$ the majority of physicians surveyed $(83.3 \%$ ) reported that they did not receive any information concerning when tooth avulsion occurred.

Appropriate replantation of an avulsed permanent tooth within $30 \mathrm{~min}$ has a $90 \%$ chance of success. After $2 \mathrm{~h}$, there is negligible (5\%) chance of long-term retention of the tooth. [23] An attempt should, thus, be made to immediately replant the avulsed tooth. Last part of the questionnaire in this survey includes questions related to the topics considered very important for the prognosis of avulsed permanent teeth. We evaluated the duration between trauma occurrences and re- 
ferring the patient for professional help after avulsion; $26.19 \%$ physicians replied immediately, 15.87\% replied within 30-60 min, $12.70 \%$ replied within a few hours, and $19.05 \%$ replied within $24 \mathrm{~h}$. Furthermore, $7.14 \%$ physicians stated that there is no need for professional help and $19.05 \%$ did not have any idea.

In this study, only $10.32 \%$ physicians chose the appropriate management technique for an avulsed tooth. Ulusoy et al. ${ }^{[16]}$ stated that approximately half of the respondents were not aware of the appropriate procedures regarding replantation of avulsed permanent $(42.0 \%)$ or primary $(47.8 \%)$ teeth. Furthermore, approximately half of the respondents identified appropriate clinical procedures prior to replantation, such as proper cleaning (wash briefly under cold running water for a few seconds without touching the tooth) and handling techniques (from crown area) of an avulsed tooth before replantation.

Hamilton et al. ${ }^{[24]}$ obtained worse results in a study on root surface preparation when compared with this study. They stated that $28.5 \%$ respondents would scrub the tooth prior to replantation, $8.5 \%$ would wash and scrub the tooth with cotton, and $43.9 \%$ would wash the tooth with an antiseptic solution.

The significance of the media is to preserve the vitality of the periodontal ligament. The type of storage media required for avulsed permanent teeth were mainly responded to correctly. In this study, $62.7 \%$ physicians chose saline solution; $35 \%$ of the participants considered sterile saline as the best medium for storage and transportation in the study of Subhashraj et al. ${ }^{[14]}$ In our study, $8.73 \%$ participants recognized that an avulsed tooth should be intraorally transported, while in the studies by Lin et al. ${ }^{[18]}$ and Díaz et al., ${ }^{[15]} 13.2 \%$ and $9.8 \%$ of the participants, respectively, responded that the best transport medium for an avulsed tooth is saliva. In the study of Subhashraj et al., ${ }^{[14]}$ none of the participants was aware that patient's mouth (saliva) may also function well as a storage medium. In this study, 3.97\% (a low percentage) of the physicians described "milk" as an alternative storage medium. In the study of Díaz et al., ${ }^{[15]} 40 \%$ of the respondents stated milk as a storage medium.

A majority (80.96\%) of respondents in this study, while $72.4 \%$ Turkish ED physicians in another study, ${ }^{[16]}$ stated that they would prescribe antibiotics and anti-inflammatory medicaments following avulsion, which was considered the correct response regarding treatment.

Most (81.75\%) of the emergency physicians would refer the patient to a medical doctor after avulsion; $7.94 \%$ would choose a medical doctor. Only $1.59 \%(n=2)$ would refer the patient to a pediatric dentist, which was very low. In the study of Ulusoy et al., ${ }^{[16]}$ it is stated that only I 3 (I8.8\%) participants would refer the patient to a pediatric dentist. Hamilton et al. ${ }^{[2]}$ and Addo et al. ${ }^{[3]}$ highlighted that the physicians are frightened of hurting the child and of the possible legal implications of incorrectly replanting the tooth. In our study, $27.78 \%$ of the participants refused to treat the child because of legal issues and $44.44 \%$ found their knowledge about dental trauma to be inefficient.

Physicians' previous experience of dental trauma ratio was found to be $55.56 \%$ in this study; $88.89 \%$ of the participants were unaware of the dental emergency clinics and their working hours in Istanbul. Published studies have revealed that physicians have an inadequate understanding of how to provide appropriate first-aid when confronted with TDI. ${ }^{10,14-}$ 20] One study from Turkey ${ }^{[16]}$ stated that most (66.7\%) participants were unaware of the urgency of seeking professional care following TTAI. In this study, $84.92 \%$ of the physicians found their knowledge about dental trauma to be insufficient and $80.80 \%$ volunteered to get educated.

\section{Conclusion}

Dental trauma may occur as an isolated injury or as a component of a severe maxillofacial injury. Physicians sometimes perform emergency dental treatment because emergency dental practitioners are rarely present in either public or university hospitals in Turkey. This study indicates a lack of adequate knowledge about TDI among physicians, similar to reports published over the last decade. Most of the physicians did not attend any training on dental trauma management or oral health during their educational or professional career. Regarding their unsatisfactory knowledge about dental trauma and enthusiasm for education, a dental trauma management training should be organized with the guidance of dental faculties. Continuing education, postgraduate programs, interdisciplinary seminars, case discussions, clinical posters, and flow charts with clinical guidelines for TDI management in emergency rooms should be provided to emergency physicians to help improve their level of knowledge on the emergency management of dentoalveolar tooth injuries. In addition, efforts by local dental organizations should provide emergency doctors with lists of dentists who are knowledgeable and willing to be available $24 \mathrm{~h}$ a day for consultation and, if necessary, provide timely management to the individuals sustaining TDI. These efforts would enhance the longterm outcomes for patients experiencing dental trauma who require emergency management.

\section{Conflict of interest: None declared.}

\section{REFERENCES}

1. Hamdan MA, Rajab LD. Traumatic injuries to permanent anterior teeth among 12-year-old schoolchildren in Jordan. Community Dent Health 2003;20:89-93.

2. Hamilton FA, Hill FJ, Mackie IC. Investigation of lay knowledge of the management of avulsed permanent incisors. Endod Dent Traumatol 1997;13:19-23. [CrossRef]

3. Kramer PF, Zembruski C, Ferreira SH, Feldens CA. Traumatic dental 
injuries in Brazilian preschool children. Dent Traumatol 2003;19:299303. [CrossRef]

4. Gassner R, Bösch R, Tuli T, Emshoff R. Prevalence of dental trauma in 6000 patients with facial injuries: implications for prevention. Oral Surg Oral Med Oral Pathol Oral Radiol Endod 1999;87:27-33. [CrossRef]

5. Soriano EP, Caldas Ade F Jr, De Carvalho MV, Caldas KU. Relationship between traumatic dental injuries and obesity in Brazilian schoolchildren. Dent Traumatol 2009;25:506-9. [CrossRef]

6. Andreasen JO, Andreasen FM, Skeie A, Hjørting-Hansen E, Schwartz O. Effect of treatment delay upon pulp and periodontal healing of traumatic dental injuries-a review article. Dent Traumatol 2002;18:116-28.

7. Levin L, Ashkenazi M, Schwartz-Arad D. Preservation of alveolar bone of un-restorable traumatized maxillary incisors for future implantation. J Israel Dent Assoc 2004;21:54-9.

8. Schwartz-Arad D, Levin L, Ashkenazi M. Treatment options of untreatable traumatized anterior maxillary teeth for future use of dental implantation. Implant Dent 2004;13:120-8. [CrossRef]

9. Schwartz-Arad D, Levin L. Post-traumatic use of dental implants to rehabilitate anterior maxillary teeth. Dent Traumatol 2004;20:344-7.

10. Holan G, Shmueli Y. Knowledge of physicians in hospital emergency rooms in Israel on their role in cases of avulsion of permanent incisors. Int J Paediatr Dent 2003;13:13-9. [CrossRef]

11. Needleman HL, Stucenski K, Forbes PW, Chen Q, Stack AM. Massachusetts emergency departments' resources and physicians' knowledge of management of traumatic dental injuries. Dent Traumatol 2013;29:2729. [CrossRef]

12. Aren G, Sepet E, Pinar Erdem A, Tolgay CG, Kuru S, Ertekin C, et al. Predominant causes and types of orofacial injury in children seen in the emergency department. Ulus Travma Acil Cerrahi Derg 2013;19:24650. [CrossRef]

13. Addo ME, Parekh S, Moles DR, Roberts GJ. Knowledge of dental trauma first aid (DTFA): the example of avulsed incisors in casualty departments and schools in London. Br Dent J 2007;202:E27. [CrossRef]
14. Subhashraj K. Awareness of management of dental trauma among medical professionals in Pondicherry, India. Dent Traumatol 2009;25:92-4.

15. Díaz J, Bustos L, Herrera S, Sepulveda J. Knowledge of the management of paediatric dental traumas by non-dental professionals in emergency rooms in South Araucanía, Temuco, Chile. Dent Traumatol 2009;25:611-9. [CrossRef]

16. Ulusoy AT, Onder H, Cetin B, Kaya S. Knowledge of medical hospital emergency physicians about the first-aid management of traumatic tooth avulsion. Int J Paediatr Dent 2012;22:211-6. [CrossRef]

17. Abu-Dawoud M, Al-Enezi B, Andersson L. Knowledge of emergency management of avulsed teeth among young physicians and dentists. Dent Traumatol 2007;23:348-55. [CrossRef]

18. Lin S, Levin L, Emodi O, Fuss Z, Peled M. Physician and emergency medical technicians' knowledge and experience regarding dental trauma. Dent Traumatol 2006;22:124-6. [CrossRef]

19. Qazi SR, Nasir KS. First-aid knowledge about tooth avulsion among dentists, doctors and lay people. Dent Traumatol 2009;25:295-9.

20. Trivedy C, Kodate N, Ross A, Al-Rawi H, Jaiganesh T, Harris T, et al. The attitudes and awareness of emergency department (ED) physicians towards the management of common dentofacial emergencies. Dent Traumatol 2012;28:121-6. [CrossRef]

21. Boyd DH, Kinirons MJ, Gregg TA. A prospective study of factors affecting survival of replanted permanent incisors in children. Int J Paediatr Dent 2000;10:200-5. [CrossRef]

22. McIntyre JD, Lee JY, Trope M, Vann WF Jr. Elementary school staff knowledge about dental injuries. Dent Traumatol 2008;24:289-98.

23. Andreasen JO, Hjorting-Hansen E. Replantation of teeth. I. Radiographic and clinical study of 110 human teeth replanted after accidental loss. Acta Odontol Scand 1966;24:263-86. [CrossRef]

24. Hamilton FA, Hill FJ, Holloway PJ. An investigation of dento-alveolar trauma and its treatment in an adolescent population. Part 1: The prevalence and incidence of injuries and the extent and adequacy of treatment received. Br Dent J 1997;182:91-5. [CrossRef]

\title{
ORIJINAL ÇALIŞMA - ÖZET
}

\section{Acil servislerde travmatik dental yaralanmaların tedavisi konusunda bilginin önemi \\ Dr. Acar Aren, ${ }^{1}$ Dr. Arzu Pınar Erdem, ${ }^{2}$ Dr. Gamze Aren, ${ }^{2}$ Dr. Zeynep Deniz Şahin, ${ }^{1}$ Dr. Ceren Güney Tolgay, ${ }^{2}$ Dr. Merve Çayırcı, ${ }^{2}$ Dr. Elif Sepet,, ${ }^{2}$ Dr. Recep Güloğlu, ${ }^{3}$ Dr. Hakan Yanar, ${ }^{3}$ Dr. Kaya Sarıbeyoğlu ${ }^{4}$}

\author{
${ }^{1}$ Istanbul Eğitim ve Araştırma Hastanesi, Genel Cerrahi Kliniği, İstanbul \\ ${ }^{2}$ İstanbul Üniversitesi Dişhekimliği Fakültesi, Pedodonti Anabilim Dalı, İstanbul \\ ${ }^{3}$ İstanbul Üniversitesi İstanbul Tıp Fakültesi, Genel Cerrahi Anabilim Dalı, İstanbul \\ ${ }^{4}$ İstanbul Üniversitesi Cerrahpaşa Tıp Fakültesi, Genel Cerrahi Anabilim Dalı, İstanbul
}

AMAÇ: Hastane acil servisleri hem travmatik hem de travmatik kökenli olmayan acil dental durumlarla karşı karşıya gelirler. Öte yandan literatür, tıp uzmanları arasında travmatik dental yaralanmalarının (TDY) yönetimi konusunda bilgi eksiklikleri bulunduğunu ileri sürmektedir. Bu çalışanın amacı, İstanbul acil cerrahi doktorlarının TDY'nin tedavisine yönelik bilgi ve tutumlarını araştırmaktır.

GEREÇ VE YÖNTEM: Anketler acil servis yöneticilerine ve doktorlara dağıtıldı. Anket, özellikleri ve dental travma yönetimi konusundaki bilgilerini değerlendiren soruları içermekteydi.

BULGULAR: Toplamda 126 anketin (I3'ü acil sevis yöneticisi, I I 3 doktor) geri dönüşü olmuş ve değerlendirme kapsamına alınmıştır. Acil çalışanlarının kron kırıkları ve avülsiyon konusundaki uygun tedavi bilgi düzeyleri genelde iyi düzeyde olmasına karşın $(p=0.22 \mathrm{I})$, lüksasyon yaralanmalarda konusundaki bilgileri yetersizdi $(p=0.000$ I). Doktorlar kalııı dişler konusunda süt dişlerine oranla daha iyi bir bilgi düzeyine sahiplerdi $(p=0.027)$. TARTIŞMA: Bu çalışmadan elde edilen bulgulara dayanarak, hastanelerde özellikle doktorlar arasında TDY yönetimini iyileştirmek için eğitim, izleme, kaynakların daha iyi kullanılabilirliği ve disiplinler arası uyum eksikliğinin değerlendirilmesi gereklidir. Anahtar sözcükler: Acil girişim; dental avülsiyon; travmatik diş yaralanmaları.

Ulus Travma Acil Cerrahi Derg 2018;24(2):136-144 doi: 10.5505/tjtes.2017.57384 